\title{
PENGELOLAAN ADMINISTRASI KEUANGAN SEKOLAH PADA YAYASAN MANGGALA TAMA DI KOMPLEK PERMATA PAMULANG, TANGERANG SELATAN
}

\author{
${ }^{1}$ Taufik Hidayat, ${ }^{2}$ Amelia Christine Hapsari, ${ }^{3}$ Alifya Haniffa Suryaman, \\ ${ }^{4}$ Dicky Akbar Yulianvera, ${ }^{5}$ Muhamad Syahrul Rhamadan \\ Universitas Pamulang, Tangerang Selatan, Banten, Indonesia \\ Email : *taufik081295@gmail.com
}

Manuskrip: Desember -2021; Ditinjau: Januari -2022; Diterima: Januari -2022;

Online: Januari-2022; Diterbitkan: Januari-2022

\begin{abstract}
ABSTRAK
Pengabdian ini berjudul pengelolaan administrasi keuangan sekolah pada yayasan manggala tama di komplek permata pamulang tangerang selatan. Tujuan umum dari kegiatan pengabdian kepada masyarakat ini adalah Memberikan sharing dan pengetahuan secara praktis ilmu manajemen dalam pengelolaan administrasi keuangan sekolahpada yayasan manggala tama. Metode yang digunakan adalah metode survey dan penyampaian materi secara langsung serta simulasi dan diskusi mengenai manajemen, pengelolaan keuangan, pemasaran produk dan penerapan MSDM dalam pengelolaan administrasi keuangan sekolah pada yayasan menggala tama yang berdampak pada positif ke pada tenaga atau para pengejara. Kesimpulan dari pengabdian kepada masyakat ini adalah bahwa akan dilakukan pendampingan dalam manajemen dalam pengelolaan administrasi keuangan sekolah pada yayasan manggala tama dengan dibentuk kelompok-kelompok pengelolaan administrasi keuangan sekolah pada yayasan maggala tama.
\end{abstract}

\section{Kata Kunci: Administrasi, Keuangan Sekolah}

\section{PENDAHULUAN}

Sekolah sebagai sebuah lembaga pendidikan yang didalamnya terdiri dari satuan unit Taman kanak-kanak, sekolah dasar, sekolah menengah pertama dan sekolah menengah atas adalah sebuah tempat dimana tujuan dari pendiriannya adalah mencetak generasi yang memiliki kemampuan bersaing ketika telah dewasa. Tujuan lain dari pendirian sekolah adalah untuk mencerdaskan bangsa sebagaimana disebutkan dalam Undang-Undang Dasar 1945 (Renstra Depdiknas, 2010-2014). Bangsa yang cerdas memiliki point lebih ketika dihadapkan dengan bangsa lain. Kecerdasan dari sebuah anak didik tak terlepas dari peran stakeholder dalam membina dan mengembangkan sekolah menjadi tempat untuk anak didik menjadi pribadi yang unggul dalam segala bidang.

Peran stakeholder dalam menyelenggarakan pendidikan ditopang dengan pembiayaan yang baik. Biaya merupakan salah satu unsur yang sangat penting dalam penyelenggaraan pendidikan. Penentuan biaya akan mempengaruhi tingkat 
efisiensi dan efektivitas kegiatan di dalam suatu organisasi. Jika suatu kegiatan dilaksanakan dengan biaya yang relatif rendah, tetapi menghasilkan produk yang berkualitas tinggi, maka hal ini dapat dikatakan bahwa kegiatan tersebut dilaksanakan secara efisien dan efektif (Bakrun M, 2019). Mekanisme pembiayaan dapat dilakukan melalui berbagai pendekatan. Salah satu pendekatan yang sering digunakan adalah pendekatan sistem, yaitu pendekatan yang berorientasi pada tujuan, alternatif, dan efektivitas (Bakrun $\mathrm{M}$, tersebut sampai enam bulan kedepan dengan mempertimbangkan likuiditas keuangan UMKM. Termasuk juga menyederhanakan proses administrasi mendapatkan pinjaman di tengah situasi darurat ini.

Penerimaan pajak turun sejalan dengan tax expenditure meningkat. Peningkatan tax expenditure akan meningkatkan government expenditure, yang memberikan multiplier effect pada perekonomian nasional, diantaranya adalah peningkatan daya beli masyarakat yang akan meningkatkan PPN, serta stabiltas ekonomi, produktifitas usaha dan manajemen kas yang sehat diharapkan dapat meningkatkan potensi PPh terutang setelah periode insentif berakhir.

\section{METODE PELAKSANAAN KEGIATAN}

Melihat permasalahan yang dihadapi maka langkah-langkah yang dilakukan untuk mencapai tujuan dan sasaran kegiatan ini maka diadakan pendekatan kepada instansi terkait yaitu masyarakat melalui penyampaian materi berupa penjelasan tujuan manajemen administrasi keuangan sekolah dalam upaya dan strategi mewujudkan yayasan sejahtera mandiri untuk membantu di Yayasan Manggala Tama. Pengabdian Kepada Masyarakat (PKM) akan dilaksanakan di Komplek Permata Pamulang, kota Tangerang Selatan, Provinsi Banten, pada bulan November 2021. Pembuatan ini akan dibimbing oleh tim pelaksana staf-staf pengajar dari Universitas Pamulang dengan mengikut sertakan peran instansi terkait baik pengurus dan pengajar di Yayasan Manggala Tama. Metode pelatihan yang diterapkan berdasarkan solusi atas permasalahan di Yayasan Manggala Tama Pengabdian Kepada Masyarakat (PKM) akan dilaksanakan di Komplek Permata Tama, Kota Tangerang Selatan, Provinsi Banten pada bulan November 2021, Metode Kegiatan : Presentasi, Diskusi dan tanya jawab seputar manajemen dalam pengembangan administrasi keuangan sekolah.

\section{HASIL DAN PEMBAHASAN}

Prinsip-prinsip keuangan sekolah meliputi prinsip transparan yang memberikan informasi yang jelas kepada pihak-pihak yang berkepentingan tantang dari mana sumber data diperoleh, berapa jumlah yang digunakan. Prinsip efisiensi biasanya diukur dengan membandingkan antara masukan atau yang digunakan dengan yang dikeluarkan atau yang dihasilkan. Prinsip Akuntabilitas digunakan harus di pertanggungjawabkan baik secara administratif maupun secara normative.

Pertanggungjawaban administrasi disini maksudnya adalah penggunaan keuangan sekolah jelas pembukuannya, ada bukti-bukti penggunaannya, serta 
hasilnya. Proses Administrasi Keuangan meliputi Penyusunan RPS dan Penyusunan RKAS.

Persyaratan pendaftaran NPWP (Pengusaha) antara lain fotokopi KTP, fotokopi surat keterangan usaha atau SKU (disebut juga SKU) dinas atau dinas terkait izin usaha, dan fotokopi akta keluarga (wajib apabila yang pendaftar seorang istri) Selain itu, diperlukan juga formulir pernyataan bisnis yang ditandatangani dengan materai Rp. 6000, dan mengisi formulir pendaftaran NPWP yang disediakan oleh biro pajak dan ditandatangani oleh pemohon.

Persyaratan semua dokumen sudah lengkap, pendaftaran NPWP tidak perlu menunggu lama. Bahkan selain langsung ke biro pajak, Anda juga bisa mengisi data diri di laman online melalui https://ereg.pajak.go.id untuk melengkapi registrasi NPWP, namun untuk registrasi NPWP dilakukan. dapat merekomendasikan kami untuk pergi langsung ke Departemen Pendapatan Pedalaman. Pendaftaran NPWP telah selesai dilaksanakan, maka kewajiban yang harus dipenuhi oleh wajib pajak usahawan adalah melakukan pembayaran dan pelaporan pajak. Pembayaran dilakukan setiap bulan dengan memperhitungkan omzet yang diperoleh pada bulan yang bersangkutan. Kemudian omzet itu dikalikan dengan tarif $0,5 \%$ untuk omzet yang diperoleh sejak bulan Juli 2018 hingga sekarang.

Pembayaran telah dilakukan, langkah terakhir adalah melaporkan SPT tahunan. Laporan tahunan SPT ini dapat diselesaikan di KPP atau melalui situs online Pajak.go.id. Batas waktu penyampaian SPT tahun ini mulai Januari tahun berikutnya hingga Maret tahun berikutnya. Misalnya, jika ingin melaporkan SPT tahunan tahun pajak 2019, harap laporkan dari Januari 2020 hingga Maret 2020. Dengan kemajuan teknologi yang semakin memudahkan wajib pajak, diharapkan para pelaku UMKM khususnya seluruh pelaku UMKM di Indonesia secara umum dapat memenuhi kewajiban perpajakannya secara tertib.hidupnya.

\section{KESIMPULAN}

Mengadakan Pengabdian Kepada Masyarakat Lanjutan Pada masa COVID19 masyarakat dihimbau agar mematuhi protokol kesehatan secara 5 M (Memakai masker, Mencuci tangan, Menjaga jarak, Membatasi Mobilitas, Menjauhi kerumuman).

Maka untuk mengurangi resiko terpaparnya COVID-19, administrasi keungan yayasan dapat dilakukan secara digitalisasi. Digitalisasi itu sendiri dengan cara penggunaan sebuah sistem virtual account (VA) yang mana nanti bias ditagihkan secara langsung kepada orang tua/wali murid. VA ini dapat mempermudah kedua belah pihak baik yayasan maupun orang tua/wali karena dapat ditagihkan secara langsung sesuai dengan jadwal dan nominal yang sudah ditentukan.

Proses pembuatan laporan lebih efisien dsn lebih terpantau karena ditarik langsung dari sistem tersebut yang dapat berupa data dalam bentuk excel. Data excel tersebut dapat diolah menggunakan makro yang sudah paten sehingga pembuatan laporan lebih akurat dan waktu yang digunakan cenderung lebih singkat. 
1. Mendorong alokasi dana desa tidak selalu digunakan untuk pembangunan infrastruktur saja, tetapi juga dapat dialokasikan untuk sarana dan prasarana yang lebih dibutuhkan oleh masyarakat khususnya pembuatan intalasi agroindustri biogas dari limbah kotoran sapi untuk memenuhi kebutuhan gas di daerah tersebut

2. Agar seluruh elemen desa dapat bekerjasama dalam membangun sarana dan prasarana intalasi agroindustri biogas dari limbah kotoran sapi guna menaggulangi ketergantungan gas di daerah Desa Sindanglaya, Kec. Tanjungsiang, Kab. Subang Propinsi Jawa barat.

3. Agar para peternak sapi mendapatkan perhatian yang lebih pemerintah maka harus dibuat kelompok - kelompok tani yang lebih terorganisasi.

\section{DAFTAR PUSTAKA}

Anggakara, P., Sudarno, Wardhana, I.W. 2013. Pengaruh Pengelolaan Administrasi keuangan sekolah. EJournal UNDIP. 2(3) : 1-8.

Azizah, N.A. 2017. 2017, Penyediaan Daging dari Sapi Lokal Ditarget Naik. diakses tanggal 03 Desember 2021.

Fitradiansyah, D.R. 2008. Administrasi Keuangan sekolah (Kecamatan Timur) Mandiri Energi. Institut Teknologi Sepuluh November. Surabaya. 25 hlm.

Guitman LJ, Z. C. (2012). Principles of Managerial Financial Global Edition 13th Edition. England:: Person Education Limited 2012.

Gujarati Damodar N, F. D. (2013). Basic Econometrics, 5th Edition. Diterjemahkan oleh: Eugenia Mardanugraha, Sita Mardani, Carlos Mangunsong. (2013). Dasar-dasar Ekonometrika. Jakarta:: Salemba Empat.

Hambali, E., S. Mujdalipah., A.H. Tambunan., A.W. Pattiri dan R. Hendroko. 2007. Teknologi Bioenergi. PT Agromedia Pustaka, Jakarta. $124 \mathrm{hlm}$

Haque, MG., Munawaroh, Sunarsi, D., (2020). Analysis of SMEs Culinary Marketing Strategy During Covid 19 Pancemic: A Study at "Sate Bebek Cilegon" Resto in Cilegon, Banten. International Journal of Education, Information Technology, and Others. Vol.3. Issue 2

Haryati, T. 2006. Biogas: Limbah Peternakan yang Menjadi Sumber Energi Alternatif. Jurnal Wartazoa. 16(3) : 160-169.

Hastuti, D. 2009. Aplikasi Teknologi Biogas Guna Menunjang Kesejahteraan Petani Ternak. Jurnal ilmu-ilmu pertanian. 5(1) : 20-26.

Houston, B. \&. (2013). Essential of Financial Management. Original edition first published by Cengage Learning 2007,Diterjemahkan oleh: Ali Akbar Yulianto. 2011. Dasar-dasar Manajemen Keuangan. Buku 1-2. Jakarta: Id.wikipedia.org tahun 2018

Iskandar, J. (2016). Indek dan Skala dalam Penelitian. Bandung: Puspaga.

Kasmir. (2014). Analisis Laporan Keuangan. Jakarta: PT. Raja Grafindo Persada. Taufik dan Eka Avianti Ayuningtyas. 2020. Dampak Pandemi Covid-19 Terhadap Bisnis dan Eksistensi Platform Online. Sekolah Tinggi Ilmu Ekonomi IPWI Jakarta p-ISSN 1411-710X e-ISSN 2620-388X. 